\title{
Enacting Scenario Card-Lesson Study in Pre-service Teacher Education: A Case Study on Indonesian Pre-service Teachers with Disabilities
}

\author{
Luluk Sri Agus Prasetyoningsih ${ }^{1}$, Prayitno Tri Laksono ${ }^{2}$
}

DOI: 10.35445/alishlah.v13i2.1014

\section{Article Info}

Keywords:

Scenario-card lesson study;

Pre-service teacher with

disabilities;

Pre-service teacher

education; $n$

Materials development

Kata kunci:

Lesson study kartu

scenario;

Calon guru

berkebutuhan khusus;

Pendidikan calon guru;

Pengembangan materi

\begin{abstract}
Pre-service teachers are agents involved in several teaching training before involving in the professional community. The present study was designed to look at the enactment of Scenario Card-Lesson Study (SCLS), a previously developed learning media. A single pre-service teacher with disabilities was voluntarily involved in the project. Data were garnered through multiple video-recorded observations and checklist documentation. Findings suggest that the participant demonstrated contextual practices of classroom teaching using SCLS. Based on the themed-finding, the participant designed the lesson plan effectively, improved classroom teaching skills, and wrote the lesson study report well. In addition, based on our observation session, The participant also engaged fully in student-student discussion and teacher-student interactions. One tangible finding from this study is that the participant appeared autonomous in designing the teaching and learning plans. Suggestions for policymakers, stakeholders, and future researchers in pre-service teacher education are offered in this paper.
\end{abstract}

\begin{abstract}
Abstrak
Mahasiswa calon guru adalah agen yang terlibat dalam sejumlah pelatihan mengajar sebelum terjun ke dunia profesional. Penelitian ini dirancang untuk melihat implementasi Scenario Card-Lesson Study (SCLS), media pembelajaran yang dikembangkan sebelumnya. Seorang calon guru penyandang disabilitas secara sukarela terlibat dalam proyek peneitian ini. Data dikumpulkan melalui beberapa pengamatan yang direkam dengan video dan dokumentasi checklist. Temuan penelitian ini menunjukkan bahwa peserta mendemonstrasikan praktik pengajaran di dalam kelas dengan kontekstual menggunakan SCLS. Berdasarkan tema dalam temuan tersebut, peserta dapat merancang RPP secara efektif, keterampilan mengajar peserta di kelaspun meningkat, dan dapat menulis laporan lesson study dengan baik. Selain itu, berdasarkan sesi observasi dalam penelitian ini, peserta juga terlibat penuh dalam interaksi guru-siswa. Salah satu temuan nyata dari penelitian ini adalah bahwa peserta tampak mandiri dalam merancang rencana pembelajaran. Berdasarkan semua temuan ini, saran untuk pembuat kebijakan, pemangku kepentingan, dan peneliti selanjutnya dalam pendidikan calon guru didiskusikan di akhir makalah ini.
\end{abstract}

\footnotetext{
${ }^{1}$ Universitas Islam Malang, Malang, Indonesia Email: luluksap58@unisma.ac.id 2 Universitas Islam Malang, Malang, Indonesia
} 


\section{INTRODUCTION}

Pre-service education has been of great interest in research among scholars. In particular, there has been a growing concern on pre-service teachers' teaching and learning process in the classroom context in the last decades (Lim et al., 2018; Owiny et al., 2019; Quinlan, 2020; Zhang et al., 2018). Research to date has much focused on pre-service teacher reflection (Karlström \& Hamza, 2019), pre-service teacher beliefs (Othman \& Kiely, 2016), pre-service teacher teaching practicum (Maidou et al., 2020), and pre-service teacher identity construction (Trent, 2012). The studies above have greatly contributed to positive findings of pre-service teacher research in the educational landscape. Despite this, there is a scarcity of research exploring how a single preservice teacher enacts the teaching and learning process employing a specific learning approach during the class. The presents study was designed to uncover the implementation of a previously developed learning product, Scenario Card-Lesson Study (SCLS), in an Indonesian pre-service teacher program enacted by a pre-service teacher with disabilities.

Teacher competence can be done through extensive teaching practices. Both pre-service and in-service teachers can do this. In the university context, where a teacher education preparation program is carried out, undergraduate students are likely to practice teaching in the schools through internship programs (Siri et al., 2020). Teaching practice is a compulsory subject taken by all students at the faculty of teacher training and education. During the teaching practice activity, the student teachers have exposed a real-life experience of teaching and learning where they implement their academic, cognitive competencies, such as teaching competence, social and negotiation competence, and educational management competence (Owens et al., 2021).

The teaching practice activity is administered at schools under several characteristics, such as (a) it is both programmed and supervised activity where every pre-service teacher is supervised by the school subject teacher, lecturer, as well as school principal and (2) the conducted teaching practice can be in the form of a lesson study (LS). Theoretically, LS is a professional guided teaching model for the pre-service teachers, which is developed through collaborative and simultaneous learning undergone through several collaborative principles where the pre-service teachers help each other achieve the community learning goals (Triyanto, 2016). One of the ways used to prepare the pre-service teachers' competence can be done via a particular training-like activity or be conducted by implementing a collective learning model (Yusuf et al., 2017). Moreover, LS per se is a skill leading to learning activities following the effort to achieve a fundamental teaching competence under a simultaneous guidance group of teachers or lecturers based on collaborative and mutual learning principles to build learning (Brodie, 2021).

In the current research, teaching practice activity at school is based on LS where it is collaboratively implemented amongst pre-service teachers with particular needs, school subject teachers, school non-subject teachers, school principals, lecturers, as well as colleagues to identifying teaching and learning problems, planning teaching and learning activities, teaching students, evaluating teaching and learning activity, and even revising teaching and learning plan. Besides, standard competency of teaching practice activity is 1) to have a skilled pre-service teacher in developing innovative learning media, 2) to have a skilled pre-service teacher conducting classroom-real teaching practice activity by using innovative learning model and media, and also 3) to have a skilled pre-service teacher in planning, implementing, and evaluating assessmentclassroom based (Omar et al., 2020). In the essence of those necessary competencies, material and activity assessment in the form of teaching practice covering orientation and observation activities, composing printed teaching and learning activities, teaching practice activity, and every single activity dealing with the classroom teaching and learning activity, including ethics and school management.

Pre-service teachers are obliged to arrange printed teaching and learning activities based on several criteria and decided components. Related to teaching practice activity, every planned

Page 1404 of 1410 
printed teaching and learning activity containing related materials is sought to consult the school subject teacher based on the subject's curriculum. Practically, every planned printed teaching and learning activity should be consulted and agreed upon by both school subject teachers and lecturers (Afalla \& Fabelico, 2020; Sarkadi et al., 2020). The number of printed teaching and learning activities done by the pre-service teacher is based on the varied materials and meetings, at least done in ten meetings. Additionally, the set of obliged teaching practice documents are syllabus and lesson plan. Even more, the pre-service teacher is suggested to be able to arrange an annual and semester program, as well as to be able to assess tested materials.

Given the importance of researching pre-service teacher's teaching practice with disabilities in an Indonesian university context and the gap of research persisting in the literature, the present study was designed to reveal the enactment of a previously developed learning product, Scenario Card-Lesson Study (SCLS), carried out by a single pre-service teacher in an Indonesian pre-service teacher program. The study specifically aims at revealing the implementation of the Scenario CardLesson Study (SCLS) method in the teaching and learning process carried out by the pre-service teacher.

\section{METHOD}

The present study was situated in a private secondary school based in Malang, East Java, Indonesia, through a scheduled teaching practice program from April to October 2019. The study aimed to investigate the teaching practice of a single pre-service teacher with disabilities on teaching Bahasa Indonesia using Scenario Card-Lesson Study (SCLS). The nature of the study was a case study (Yazan, 2015). This design was used to capture a single-based phenomenon in a specific environment. The study was involved by a single pre-service teacher mandated to teach in the studied classroom. In each meeting, the pre-service teacher's performance is based on an approved lesson plan. Moreover, the schedule of the teaching performance was set up by the school subject teacher. In practice, every pre-service teacher should at least conduct teaching practice in ten meetings. Practically, every two hours meeting equals one meeting. In addition, the teaching practice components cover several activities, As explained in Table 1 below.

Table 1. Observed-Teaching Checklist

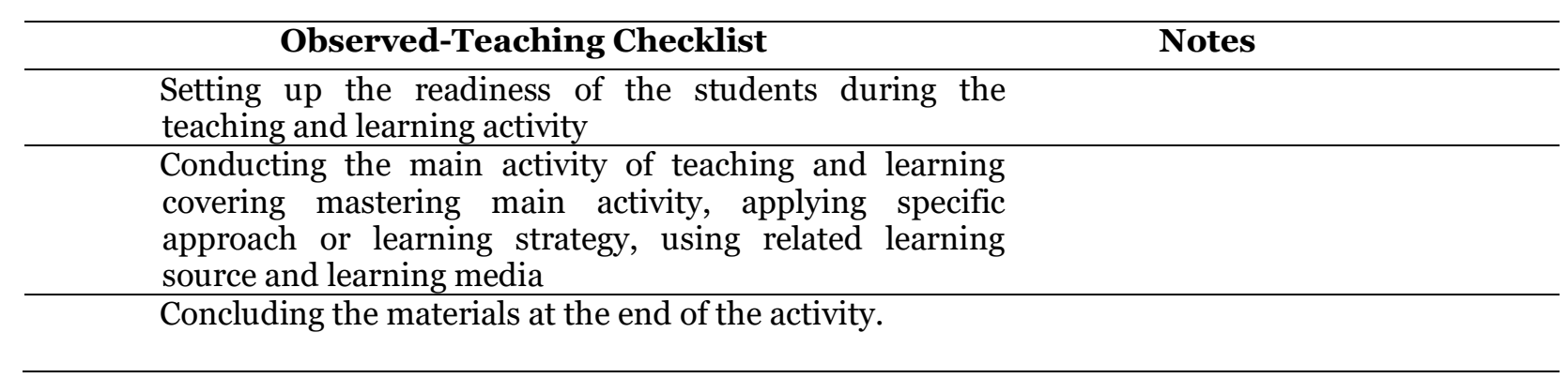

The development of SCLS as a learning media was first done using Research \& Development design in the previous project. Because this study was done to explore how SCLS was implemented in classroom teaching, video-recorded observation was conducted. Researchers employed a self-developed checklist to document pre-service teachers' performance in enacting SCLS in classroom teaching in this observation. Data from observation were analyzed qualitatively based on the emerging themes: designing lesson plans, teaching skills, and the ability to write lesson study reports (Lester et al., 2020).

\section{FINDINGS AND DISCUSSION}

The study's findings are detailed into three emerging themes from the observation activity: designing lesson plans, teaching skills, and the ability to write lesson study reports. 


\section{Designing Lesson Plan Competency}

The study reveals interesting evidence from participant's classroom teaching observations. The first salient theme emerged is the competency of designing lesson plan before coming into the class. In this regard, researchers rated several aspects of the competency, such as subject identification, learning indicator, learning objectives, learning material, learning source, learning media, learning model, learning scenario, and learning assessment. Table 1 below showcases the observation results about the participant's competency in designing a lesson plan.

Table 2. Designing Lesson Plan Competency

\begin{tabular}{lll}
\hline No. & Rated aspects & Information \\
\hline $\mathbf{1}$ & Subjects Identification & Good \\
2 & Composing Learning Indicators & Good \\
3 & Composing Learning Objectives & Good \\
4 & Selecting Learning Material & Good \\
5 & Selecting Learning Source & Good \\
6 & Selecting Learning Media & Good \\
7 & Learning Model & Good \\
8 & Learning Scenario & Good \\
9 & Learning Assessment & Good \\
\hline
\end{tabular}

The first finding from the observation shows that designing lesson plans enacted by the participant has been well-performed. As in the information column, all aspects of the lesson plan development are successfully implemented. The study concludes that the participant understands the process of creating a good lesson plan for practicing SCLS in the classroom.

The study uncovers that designing lesson plans has been well-implemented by the participant. Previous studies (see Davis et al., 2019; Drost \& Levine, 2015; Quinlan, 2020; Zhang et al., 2018) have argued that designing lesson plans in teaching is essential as it directs pre-service teachers to map out the classroom activities in a given period. Indicators of competence in designing lesson plans revealed in the present study are parts of lesson planning construction done in many educational contexts such as subject identification, learning indicator, learning objectives, learning material, learning source, learning media, learning model, learning scenario, and learning assessment. Our study also echoes a recent research study in the US that pre-service teachers who modified prior lesson plans could design lesson plans than the other pre-service teachers at the university level (Lim et al., 2018). It is therefore important for pre-service teacher education to guide student teachers in designing lesson plans effectively.

\section{Participant's Teaching Skill in the Classroom}

The second themed-finding portrayed in the present study is participant's skill in teaching students using the SCLS method. The observation checklist in this study covers three rated aspects of teaching skills: pre-teaching, main-teaching, and post-teaching activities. In the pre-teaching session, we rate three aspects: apperception, motivation, and skills in delivering competencies and planned activities. In the main teaching session, six aspects are rated: mastery of the subject, application of pedagogical learning activities, implementation of selected scientific approach and evaluation, utilization of learning resources and learning media, student involvement in learning, and proper language use. Lastly, in the post-teaching session, we rate how the participant ends the 
classroom teaching, reflection, follow-up, and up-coming materials.

Our findings also shed light that the participant could practice classroom teaching using the SCLS method well. It is found in the observation that in pre-teaching, whilst-teaching, and postteaching sessions, the participant envisions well-prepared materials, good voice, and body movement. Specifically, the study documented that the participant enacted apperception, motivational support, and prepared learning activities for the students in the pre-teaching session. Theoretically, pre-teaching session serves a pivotal role for the whole teaching and learning process (Becker et al., 2019). It is also a departure space for teachers to control the class and manage the students' learning implementation via the prepared activities. Interestingly, in the whilst-teaching session, the participant actively involved the students in learning activities by focusing on the content course taught in the class. As evidenced in the classroom observation, Table 2 indicates participant's teaching skills.

Table 3. Participant's Teaching Skill

\begin{tabular}{|c|c|c|}
\hline No. & Rated Aspects & Information \\
\hline \multirow[t]{3}{*}{1} & $\begin{array}{l}\text { Pre-Teaching Session: } \\
\text { 1) Apperception }\end{array}$ & Good \\
\hline & 2) Motivation & Good \\
\hline & $\begin{array}{l}\text { 3) Skills in delivering competencies and } \\
\text { planned activities }\end{array}$ & Good \\
\hline \multirow[t]{6}{*}{2} & $\begin{array}{l}\text { Main-Teaching Session: } \\
\text { 1) Mastery of subject }\end{array}$ & Good \\
\hline & $\begin{array}{l}\text { 2) Application of pedagogical learning } \\
\text { strategies }\end{array}$ & Good \\
\hline & $\begin{array}{l}\text { 3) Implementation of selected scientific } \\
\text { approach and evaluation }\end{array}$ & Good \\
\hline & $\begin{array}{l}\text { 4) Utilization of learning resources and } \\
\text { learning media }\end{array}$ & Good \\
\hline & 5) Students Involvement of learning. & Good \\
\hline & 6) Proper language use & Good \\
\hline \multirow[t]{4}{*}{3} & $\begin{array}{l}\text { Post-Teaching Session } \\
\text { 1) Conclusion }\end{array}$ & Good \\
\hline & 2) Reflection & Good \\
\hline & 3) Follow-up/literacy plan & Good \\
\hline & 4) Upcoming material & Good \\
\hline
\end{tabular}

The above themed-finding illustrates the flow of participant's teaching skills in the classroom. The observation portrays three stages of teaching which are done successfully by the participant. The competency to teach starts from this well-performed. This main teaching session is an important room for activities in the teaching and learning process (Becker et al., 2019). This finding is in line with the previous studies contending that teachers' role in teaching should be exclusively seen from the main teaching session (Annisa, 2014; Jabborova \& Mirsadullayev, 2020; Piercy et al., 2012). In the same vein, the participant successfully enacted the teaching and learning process in the post-teaching session. It is found that reflection on the teaching was done effectively based on our observation. This result echoes Hahl's (2021) study that teacher reflection in the postteaching could yield meaningful voices for future teaching and learning activities. 


\section{Ability to Write a Lesson Study Report}

Lastly, the study uncovers how the participants write the lesson study report in the postteaching phase. Because this part is important, the participant attempted to reflect on his teaching and construct meaning from the reflections in the form of a report. Table 4 below showcases three aspects being written. Our study also highlights that the participant successfully wrote a lesson study report. It is found in the observation session and documented in the checklist.

Table 4. Ability to Write a Lesson Study Report

\begin{tabular}{rcc}
\hline No. & Rated aspects & Information \\
\hline 1 & Lesson Plans & Good \\
2 & Implementation dan observation & Good \\
& & \\
3 & Reflection & Good \\
\hline
\end{tabular}

Three aspects were observed in this lesson study report writing: lesson plan use, the implementation of the lesson study, and the reflection at the end of the teaching and learning process. In terms of writing an effective lesson study report, the participant carried out such a task well. Lesson study has been of great concern for pre-service teaching competency. This practice can be done in the teaching internship programs. Many previous studies have portrayed the positive effects of lesson study on pre-service teachers' professional learning (Coenders \& Verhoef, 2019; Ogegbo et al., 2019; Takahashi \& McDougal, 2016). The present study's findings confirm the existing literature on lesson study implementation. It is found in the observation that the participant also included lesson plan, implementation, and reflection as the reports of the lesson study.

\section{CONCLUSION}

This study has explored the teaching practice of a single pre-service teacher with disabilities employing Scenario Card-Lesson Study in classroom teaching. The study specifically documents the participant's teaching practice from three themed findings: designing lesson plans, teaching skills, and writing lesson study reports. These findings shed light of the importance of understanding pre-service teacher agency and identity in enacting a specific teaching strategy in the classroom. As scholars have examined previously, agency and identity focused on in-service teachers and professional teachers (see Kayi-Aydar, 2019; Tao \& Gao, 2017). Therefore, the study's findings may be a catalyst for investigating the agency and identity of pre-service teachers.

Based on the findings, it is suggested that educational stakeholders implement Scenario Card-Lesson Study in teacher education institutions and provide pre-service teachers with how to practice the method effectively. It is also recommended that designing lesson plans, teachers' teaching skills, and their ability to report lesson study shall be the core focus in classroom teaching. Future research is encouraged to explore this issue using collaborative action research to uncover how pre-service teachers work with school teacher mentors and position themselves in a professional learning community.

\section{REFERENCES}

Afalla, B. T., \& Fabelico, F. L. (2020). Pre-service teachers' pedagogical competence and teaching efficiency. Journal of Critical Reviews. https://doi.org/10.31838/jcr.07.11.36

Annisa, M. (2014). Teaching Writing Descriptive Text by Using Crossword Puzzle for Second Grade of Junior High School Students. Journal of English Language Teaching. https://doi.org/10.24036/jelt.v2i2.3720

Becker, E. S., Waldis, M., \& Staub, F. C. (2019). Advancing student teachers' learning in the teaching practicum through Content-Focused Coaching: A field experiment. Teaching and Teacher Education. https://doi.org/10.1016/j.tate.2019.03.007

Brodie, K. (2021). Teacher agency in professional learning communities. Professional Development in Education. https://doi.org/10.1080/19415257.2019.1689523 
Coenders, F., \& Verhoef, N. (2019). Lesson Study: professional development (PD) for beginning and experienced teachers. Professional Development in Education. https://doi.org/10.1080/19415257.2018.1430050

Davis, A., Griffith, R., \& Bauml, M. (2019). How pre-service teachers use learner knowledge for planning and in-the-moment teaching decisions during guided reading. Journal of Early Childhood Teacher Education. https://doi.org/10.1080/10901027.2018.1534161

Drost, B. R., \& Levine, A. C. (2015). An Analysis of Strategies for Teaching Standards-Based Lesson Plan Alignment to Preservice Teachers. Journal of Education. https://doi.org/10.1177/002205741519500206

Hahl, K. (2021). Student teachers' experiences of using photos in teacher reflection. Reflective Practice. https://doi.org/10.1080/14623943.2020.1854212

Jabborova, D., \& Mirsadullayev, M. (2020). Common techniques in teaching of reading. International Journal on Integrated Education. https://doi.org/10.31149/ijie.v3i1.274

Karlström, M., \& Hamza, K. (2019). Preservice Science Teachers' Opportunities for Learning Through Reflection When Planning a Microteaching Unit. Journal of Science Teacher Education. https://doi.org/10.1080/1046560X.2018.1531345

Kayi-Aydar, H. (2019). A language teacher's agency in the development of her professional identities: A narrative case study. Journal of Latinos and Education. https://doi.org/10.1080/15348431.2017.140636o

Lester, J. N., Cho, Y., \& Lochmiller, C. R. (2020). Learning to Do Qualitative Data Analysis: A Starting Point. Human Resource Development Review. https://doi.org/10.1177/1534484320903890

Lim, W., Son, J. W., \& Kim, D. J. (2018). Understanding Preservice Teacher Skills to Construct Lesson Plans. International Journal of Science and Mathematics Education. https://doi.org/10.1007/s10763-016-9783-1

Maidou, A., Plakitsi, K., \& Polatoglou, H. M. (2020). Expansive Learning of Preservice Teachers Teaching Sustainable Development during Their Practicum. World Journal of Education. https://doi.org/10.5430/wje.v10n2p181

Ogegbo, A. A., Gaigher, E., \& Salagaram, T. (2019). Benefits and challenges of lesson study: A case of teaching physical sciences in South Africa. South African Journal of Education. https://doi.org/10.1570o/saje.v39n1a1680

Omar, M. K., Zahar, F. N., \& Rashid, A. M. (2020). Knowledge, skills, and attitudes as predictors in determining teachers' competency in Malaysian TVET institutions. Universal Journal of Educational Research. https://doi.org/10.13189/ujer.2020.081612

Othman, J., \& Kiely, R. (2016). Pre-service teachers' beliefs and practices in teaching english to young learners. Indonesian Journal of Applied Linguistics. https://doi.org/10.17509/ijal.v6i1.2661

Owens, D. C., Sadler, T. D., \& Friedrichsen, P. (2021). Teaching Practices for Enactment of Socioscientific Issues Instruction: an Instrumental Case Study of an Experienced Biology Teacher. Research in Science Education. https://doi.org/10.1007/s11165-018-9799-3

Owiny, R. L., Hollingshead, A., Barrio, B., \& Stoneman, K. (2019). Engaging Preservice Teachers in Universal Design for Learning Lesson Planning. Inclusion. https://doi.org/10.1352/23266988-7.1.12

Piercy, N., Brandon-Jones, A., Brandon-Jones, E., \& Campbell, C. (2012). Examining the effectiveness of experiential teaching methods in small and large OM modules. International Journal of Operations and Production Management. https://doi.org/10.1108/01443571211284205

Quinlan, C. L. (2020). Analysis of pre-service teachers' lesson plans to determine the extent of transfer of argumentation. International Journal of Science Education. https://doi.org/10.1080/09500693.2020.1753125

Sarkadi, Casmana, A. R., \& Rahmawati, Y. (2020). Improved learning design for pre-service teacher in a character education course. Universal Journal of Educational Research. https://doi.org/10.13189/ujer.2020.080126

Siri, A., Supartha, I. W. G., Sukaatmadja, I. P. G., \& Rahyuda, A. G. (2020). Does teacher competence and commitment improve teacher's professionalism. Cogent Business and Management. https://doi.org/10.1080/23311975.2020.1781993

Takahashi, A., \& McDougal, T. (2016). Collaborative lesson research: maximizing the impact of 
lesson study. ZDM - Mathematics Education. https://doi.org/10.1007/s11858-015-0752-x

Tao, J., \& Gao, X. (2017). Teacher agency and identity commitment in curricular reform. Teaching and Teacher Education. https://doi.org/10.1016/j.tate.2017.01.010

Trent, J. (2012). Research engagement as identity construction: Hong Kong pre-service teachers' experiences of a compulsory research project. Teacher Development. https://doi.org/10.1080/13664530.2012.688677

Triyanto. (2016). Building collaborative learning through lesson study. Prosiding ICTTE FKIP UNS 2015, 1(1), 586-588. https://media.neliti.com/media/publications/169388-EN-buildingcollaborative-learning-through.pdf

Yazan, B. (2015). Three Approaches to Case Study Methods in Education: Yin, Merriam, and Stake. The Qualitative Report. https://doi.org/10.46743/2160-3715/2015.2102

Yusuf, F. N., Widiati, U., \& Sulistyo, T. (2017). Multimodal feedback provision in improving preservice teachers' competence. Indonesian Journal of Applied Linguistics. https://doi.org/10.17509/ijal.v7i2.8126

Zhang, R., Liu, X., Yang, Y., Tripp, J., \& Shao, B. Y. (2018). Pre-service science teachers' instructional design competence: Characteristics and correlations. Eurasia Journal of Mathematics, Science and Technology Education. https://doi.org/10.12973/ejmste/81553 